\title{
Synlig og usynlig religion: umarkerte bilder i kapitler om religion
}

\author{
Av Andrew John Thomas
}

Finnes det systematiske forskjeller mellom hvordan religion illustreres $i$ norske lorebøker $i$ religionsfagene? Denne artikkelen analyserer hvordan bilder uten religionsspesifikke markorer fordeles blant kapitler om individuelle religioner $i$ tilgjengelige laerebøker $i$ dag. Bildene som velges ut, viser seg å ofte brukes til å forklare, delvis forsvare, religiøse ideer. Frekvensen av slike bilder er hoyest $i$ kapitler om buddhisme, dernest kristendom, og ellers tilnoermet fravarende. Ser vi på selve bildene, kan vi oppdage konkrete teknikker som justerer leserens avstand til den illustrerte ideen. Denne ulikheten stotter tidligere forskning som viser systematiske forskjeller $i$ hvordan ulike religioner framstilles som henholdsvis eksotiske og filosofiske, og som har konsekvenser for hvordan individuelle religioner konstrueres og skal behandles $i$ klasserommet.

Nøkkelord: Religion, lærebøker, illustrasjoner, bilder, religionsforskjeller, religionsdefinisjoner

Andrew John Thomas (f. 1977), Førsteamanuensis ved Høgskolen i Østfold. Adr: Postboks 700, 1757 Halden. E-post: andrew.thomas@hiof.no

\section{INN LEDNING}

Når vi sammenlikner religioner, sammenlikner vi epler og pærer, ulik med ulik. Det er ikke slik at buddhistiske matregler tilsvarer muslimske. Verken etikk eller psykologi har samme status i alle religiøse tradisjoner. Ikke all religiøs arkitektur kan betegnes som gudshus, eller brukes på liknende måter. Derfor er det problematisk å snakke om ulike religioner som en liste med like størrelser som ikke flyter inn i hverandre.

Men lærebøker kan ikke alltid ta stilling til slike faglige spissfindigheter, og fram til fagfornyelsen har norske lærebøker delt opp feltet som om religioner var sammenliknbare enheter. Religionene presenteres vanligvis i hver sine kapitler, der de samme overskriftene går igjen i hvert kapittel. Det gir grunnlag for at lærebokforskning, ved å sammenlikne kapitler om ulike religioner, kan studere forskjeller og likheter i hvordan religioner konstrueres uten å delta i debatten om hvor sammenliknbare religioner er. ${ }^{1}$ På den måten kan denne forskningen bidra

1 Ordet «religion» brukes dermed utelukkende om religioner slik de konstrueres av kapitteldeling i lærebøker i denne artikkelen.

Prismet - IKO-Forlaget 2020

Tilgjengelig på https://journals.uio.no/index.php/prismet. Publisert under CC BY-NC 4.0. Fagfellevurdert 
til debatten om kvalitativ likhet i de pedagogiske prinsippene som brukes i faget (Kunnskapsdepartementet 2016: §2.4).

Én framgangsmåte i lærebokforskning er eksempelvis å telle opp bilder av gutter og jenter, bruk av fagbegrep, eller å bedømme hudfarge eller sosial klasse (Hickman \& Porfilio, 2012; Midtbøen, Orupabo, \& Røthing, 2014). En mer didaktisk tilnærming er å vurdere hvordan religion konstrueres som ide eller menneske (Thomas \& Rolin, 2018), eller hvorvidt religionsfagene legger opp til «læring av» eller «læring om» i kapitler viet ulike religioner (Jackson et al., 2010).

Denne artikkelen tar utgangspunkt i slike didaktiske hensyn og definerer en egen bildekategori, nemlig bilder som ikke er religiøst markerte. Eksempler inkluderer vakre solnedganger, mennesker i krisesituasjoner, blomster og vennegjenger. De inkluderes i kapitler om navngitte religioner, men utenom denne konteksten inneholder de ingen åpenbare fenomener eller tema som skulle tilsi at de har tilknytning til denne religionen.

I 2010 gjennomførte som nevnt Jackson med flere kolleger en omfattende studie av læremidler i England som vurderte blant annet hvorvidt de la opp til «læring av» eller «læring om» religion i kapitler viet navngitte religioner. Dette er uten tvil et interessant spørsmål, men rent metodisk er det umulig å sammenlikne sortering etter så innfløkte kategorier når den gjennomføres av ulike forskere. Samtidig, dersom de hadde valgt enklere og tydeligere kategorier (antall ord, bilder, eller spørsmål) hadde resultatet vært mer reliabelt, men mindre interessant.

I vårt tilfelle er antall umarkerte bilder relativt reliabelt (jeg inkluderer rådata $\mathrm{i}$ vedlegg så leseren kan vurdere selv), men den fagdidaktiske interesse av å kartlegge antall er diskutabel. Denne artikkelen vil derfor ta to komplementære tilnærminger til analysen av umarkerte bilder: i den første delen genereres statistikk om i hvor stor grad umarkerte bilder brukes i kapitler viet ulike religioner, uavhengig av lærebok; i den andre delen tolkes et utvalg av disse bildene for å si noe om den didaktiske betydningen av denne typen bilder. Den første analysen er dermed ganske reliabel, gitt at begrepet er godt definert og riktig telt. Den andre delen er mer utforskende og foreslående, men sammen svarer de på artikkelens forskningsspørsmål «Hva er distribusjonen av umarkerte illustrasjoner på tvers av kapitler viet navngitte religioner i trykte norske lærebøker i religionsfagene, og hva er de didaktiske konsekvensene av denne distribusjonen?»

\section{BAKGRUNN OG METODE}

Mye viktig forskning på religionslærebøker har vært diakron (Härenstam, 1993; Thobro, 2008, 2014, 2017, Undheim, 2017). Det er interessant å se på tidligere generasjoners faglige valg for å forstå hvordan vi havnet akkurat her. Denne artikkelen bidrar derimot til en voksende tradisjon av synkron lærebokforskning i religionsfagene (blant mange andre, Hatlebrekke 2018; Winje 2018; Jackson et 
al., 2010 og Midtbøen, Orupabo, \& Røthing, 2014) ved å utelukkende ta for seg aktuelle lærebøker religionslærere kunne velge på alle trinn på grunnskole og videregående i 2018. En oversikt over disse finnes på slutten av artikkelen. Siden dette året har nye læreplaner blitt utviklet, drøftet, og vedtatt. Det er meningen at denne undersøkelsen kan bidra til lærebokforfatteres og lærebokbrukeres refleksjon når de forbereder seg til å ta disse nye planene i bruk.

De fleste undersøkelser hittil har vært kvalitative nærlesninger der forsker opererer som en informert leser. Det vil også være min posisjon i denne artikkelens del 2: jeg kommer som didaktiker og stiller faglige spørsmål til bildene. Del én derimot er en innholdsanalyse, eller «content analysis» (se Krippendorff 2013; Neuendorf 2002 for toneangivende introduksjoner til forskningsmetoden). I del 1 er jeg altså ikke opptatt av kvalitet, intensjoner, og heller ikke av individuelle forfattere eller lærebøker. Variablene i billedanalysen er kun (1) antall umarkerte bilder og (2) religionen siden der bildet finnes, vies til.

En spennende sjanger av lærebokanalyse er studier der lærebøkene diskuteres med elever (Vestøl 2016, Vestøl et al. 2016, Winje 2014). Det ville vært interessant å vite hva elever lærer fra umarkerte bilder, men av omfangshensyn går ikke denne artikkelen inn på det. Denne artikkelen sier heller ikke noe om hvorvidt tekstene gjenspeiler klasseromspraksis.

Denne artikkelen er ikke ment som kritikk av lærebokforfattere, men en beskrivelse av et sett med tekster. Jeg studerer lærebøker for grunn- og videregående skole, men det er ingen grunn til å tro at funnene ville vært annerledes dersom vi studerte lærebøker i universitets- eller høgskolesektor, forskningsrapporter, eller aviser.

Tidligere undersøkelser tyder på at vi har behov for didaktiske undersøkelser. Da Winje skrev sin viktige rapport om billedbruk i religionslærebøker i 2003, la han merke til markerte skiller i hvordan bilder velges og brukes i de ulike religionene. Hans oppdagelse er så betydningsfull for denne artikkelen at jeg tillater meg et lengre sitat:

... bilder (og fortellinger) med bakgrunn i kristendommen ... ble oftere knyttet til allmenne problemstillinger og til elevenes egne erfaringer. Et eksempel var illustrasjonene til fortellingen om den barmhjertige samaritan, som ofte ble brukt på denne måten. Flere loerere fortalte at de hadde brukt slike bilder for å belyse allmenne verdier som hjelpsomhet og toleranse, uten å knytte dem til den kristne religion på en entydig måte. ... Motsatt ble for eksempel bilder med motiver fra Buddhas liv aldri behandlet uavhengig av en buddhistisk kontekst.

... Dersom kristen kunst allmenngjøres i større grad enn annen kunst, vil mange elever oppleve denne kunsten som mer aktuell og «noer» enn annen kunst. Og dersom ikke-kristen kunst ikke kobles på allmenne verdier og erfaringer, vil den oppleves som «jernere» enn den kristne kunsten. (Winje, 2003, s. 81) 
Winjes forskning om bilder har for det meste handlet om kunsttradisjoner, men jeg er interessert $\mathrm{i}$ om funnet hans kan generaliseres til alle bilder i kapitler om religion. Jeg har derfor valgt å telle og tolke bilder uten religionsspesifikke markører. Dette er den eneste typen bilde jeg teller, men datagrunnlaget mitt er alle eksemplene som inkluderes i kapitler viet individuelle religioner. Det vil si at vi kan identifisere hvilken religion de brukes til å undervise i fra sidetittelen, men hadde vi tatt bildet ut av konteksten, hadde det vært vanskeligere å gjette hvor de hadde havnet.

For eksempel brukes i Store Spørsmål 10 (side 202) et bilde av en stresset student. Hvis du hadde sett bildet ute av konteksten, hadde du ikke tenkt på religion i det hele tatt. Hadde man måttet gjette, kunne man kanskje tippet at det ble inkludert $i$ en samfunnsfagbok om stress, arbeid, studievaner eller muligens kjønn. I virkeligheten er den tatt fra et bildelager, og tittelen jeg fant på nettet var «Stressed Female Teenage Student Studying In Classroom». Men i denne konteksten skal bildet illustrere menneskelig behov for meditasjon, og ble brukt i et kapittel om buddhisme. Ingenting i selve bildet peker mot en tilknytning til buddhisme.

Det at det ikke er noen religiøse markører, er et negativt krav. Metodisk betyr det at bildene sorteres ut fra svaret på ja/nei-spørsmålet «finnes det religiøse markører i dette bildet?» Det vil si at så snart jeg identifiserer noen av de følgende trekkene, er bildet utelukket fra listen over umarkerte bilder:

- Et religionsspesifikt menneske (med en visuell markør eller eksplisitt beskrevet i sammenhengende tekst, «Dette er Stella, hun er sikh»)

- En religionsspesifikk handling

- En religionsspesifikk fortelling eller tekst

- En religionsspesifikk gjenstand

- Religionsspesifikk kunst (det vil si, med religiøst motiv eller av en religiøst profilert kunstner, ikke inkludert lærebokens illustratører)

Det som er igjen, kvalifiserer som det jeg kaller «umarkerte bilder».

Det vi sitter igjen med, er en svært heterogen gruppe bilder. Noen inkluderer mennesker, andre er mer naturorienterte. Veldig mange, men ikke alle, er fotografier. Noen av dem har et tydelig etisk tilknyttet motiv, for eksempel om forbrukersamfunnet. Andre viser for eksempel geometriske former eller vakre utsikter, flere har en åpenbar handling, og mange illustrerer allmenne følelser eller

2 Akkurat i dette tilfellet er det altså ikke bildet i seg selv, men den omkringliggende verbalteksten, som styrer at bildet ekskluderes. Når den omkringliggende teksten eksplisitt definerer den avbildede personen som religionsspesifikk, defineres altså bildet som religionsspesifikt. Logikken bak dette er at bildenes innhold må kunne identifiseres med et minimum av tolkning fra koderen. Vi må i minste fall vite hva som avbildes, uten å måtte tolke hva det betyr for elever eller religiøse mennesker. For å påvise asymmetri må kodingen være konsekvent, men ikke selvforklarende. Dens logikk har mer betydning for del 2, der vi må ty til spesifikke eksempler. 
verdier som vennskap eller omsorg, selv om de inkluderes i et religionsspesifikt kapittel og ikke kapitlet om allmenn etikk.

Når jeg tolker et utvalg bilder i del 2, kommer jeg til å argumentere for at umarkerte bilder har en spesifikk relasjon til allmenn læring (slik det beskrives i Breidlid \& Nicolaisen, 2011) i religionsfaget. Winje har også anvendt denne kategori (opprinnelig generert for å tolke fortellinger) til kunst (Winje 2012: 48, 280). Den typen læring er akseptabel i seg selv, men dersom den representerer et pedagogisk prinsipp, kan dens eventuelle asymmetriske distribusjon være problematisk. For en nærmere beskrivelse av hvordan umarkerte bilder forholder seg til allmenn læring og religioner som perspektivproduserende fenomener, se avsnittet om konsekvenser, under.

\section{Data}

Hva forventet jeg å finne? Winjes observasjon kan fungere som utgangspunkt: hvis umarkerte bilder virkelig er en indikator for at religiøse bilder brukes til å knytte allmenne problemstillinger tett opp til elevenes hverdagserfaringer, kan vi forvente at også denne undersøkelsen oppdager en kobling mellom dem og kristendom. I tillegg har en liknende undersøkelse (Thomas \& Rolin, 2018) av videregående lærebøker som sorterte bilder etter deres fremstilling av religiøse mennesker eller religiøse ideer, funnet at kristendom og buddhisme ble illustrert med flere idébilder enn islam, hinduisme eller jødedom. Gruppen umarkerte bilder er en mye smalere kategori enn idébildene til Thomas og Rolin (som også inkluderer illustrasjoner av fortellinger og tekster), men jeg kan i hvert fall teste hypotesen om at umarkerte bilder brukes mer i noen religioner enn $i$ andre.

Dette er ikke en vurdering av lærebøkene, så vi er ikke interessert i hvor tett de holder seg til offisielle dokumenter, men læreplanene i KRLE og religion og etikk danner viktige rammebetingelser for lærebokforfatteres valg: er det noen grunn til at hensyn til kompetansemål kan resultere i flere umarkerte bilder i noen kapitler enn $i$ andre?

Den videregående læreplanen som var gjeldende i 2018, har nøyaktig samme kompetansemål for estetikk hos de ulike religionene, nemlig at eleven skal kunne «beskrive og analysere noen estetiske og rituelle uttrykk i religionen». Den eneste relevante forskjellen jeg ser, er at etikk skal «drøftes» hos islam og den valgfrie religionen, og «beskrives og reflekteres over» hos kristendom (Utdanningsdirektoratet, 2006).

Når det gjelder 2018-læreplanen i grunnskolen, er det et prinsipp at «Likeverdige pedagogiske prinsipper skal legges til grunn» selv om «Om lag halvparten av undervisningstiden i faget skal ... brukes på kristendomskunnskap.» Dette gjenspeiles i kompetansemålene ved at mange av de samme formuleringene brukes om parallelle temaer som for eksempel estetikk, men at kristendoms- 
kapitlet inkluderer noen elementer ekstra. De mest relevante kompetansemålene for umarkerte bilder er tilstrekkelig like til at de ikke skal prima facie produsere skjevheter, for eksempel at eleven skal kunne «innhente digital informasjon om og presentere aktuelle spørsmål som opptar mange kristne/jøder/muslimer/ hinduer/buddhister» (Utdanningsdirektoratet, 2015).

Jeg kommer tilbake til denne kvalitetsmessige likheten og kvantitetsmessige ulikheten i drøftingen til slutt. Når vi analyserer funnene, kommer forskjeller i kvantitet (kristendom har nesten fire ganger så mange sider som snittet for de andre religionene) til å nullstilles ved å se på antall bilder per side i et religionskapittel heller enn antall sider totalt (se Fig. 1 under).

\section{Del 1: Statistik}

Mesteparten av bildene i lærebøker markeres religiøst. På alle de 5370 sidene fant jeg bare 65 umarkerte bilder, så datagrunnlaget er veldig lite selv om feltet er uttømmende analysert. En grunn til dette er at flere av lærebøkene ikke ga noen resultater av naturlige årsaker: det finnes serier som Hellige rom, Høytidene og Vivo fortellingsbok, der alle bildene er religiøst markerte på grunn av sjangeren. I tillegg var det en serie som behandlet faget tematisk og derfor ikke inneholdt kapitler viet spesifikke religioner (Dialogos 8-9). ${ }^{3}$

Kravet i læreplanen og opplæringsloven om kristendomsandelen i KRLE har ført til at mange flere sider vies kristendom enn hvilken som helst annen religion. Også i religion og etikk, der ingen krav stilles om at kristendom bør vektes tyngre, vies omtrent dobbelt så mange sider til kristendom enn til Islam eller den valgfrie religionen. Alle disse faktorene skaper skjevhet i statistikken. For å få fram kvalitetsforskjeller uavhengig av dette, har jeg derfor produsert frekvensdata heller enn å se på den totale mengden bilder (se rådata i et vedlegg). Datasettet presenteres følgelig som antall umarkerte bilder per 100 sider viet den enkelte religion. På den måten ser vi på forholdet mellom markerte og umarkerte bilder heller enn total mengde. Denne typen frekvensdata er heller ikke påvirket av at noen videregående lærebøker ikke inkluderer kapitler om jødedom og hinduisme i sine trykte utgaver. Data om sikhisme, Jehovas vitner, mormonkirken, nyreligiøsitet og bahaitroen på 8. - 10. trinn (der jeg ikke fant noen umarkerte) nullstilles.

3 For å synliggjøre læreverkene vi studerer her, henvises de til ved navn heller enn forfatter. All annen forskningslitteratur henvises til med forfatter og årstall som vanlig. 


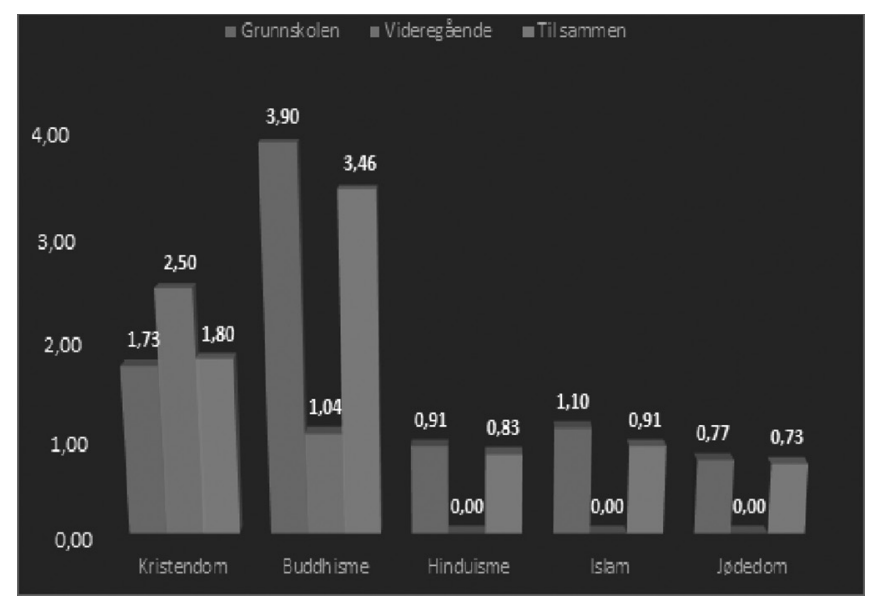

Figur 1 umarkerte bilder per 100 sider per religion

Kristendom har flest umarkerte bilder blant videregående lærebøker, men i grunnskolen og til sammen (fordi 49 av de 52 lærebøkene tilhørte grunnskolen) finner vi høyest frekvens av umarkerte bilder i kapitler om buddhisme.

En mulig forklaring på denne distribusjonen kunne vært at bestemte forfattere/ forlag foretrekker umarkerte bilder. Det viser seg at ett av læreverkene står for litt under en fjerdedel av tilfellene av denne typen bilde, men jeg mener likevel at det ikke handler om individuelle preferanser. Vi kan se på hvordan antallet bilder distribueres blant lærebøkene:

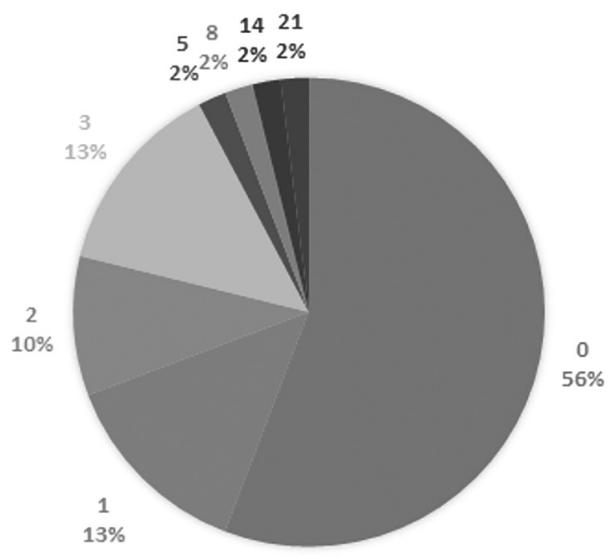

Figur 2 Fordeling antall umarkerte bilder per religionslarebok (uansett religion)

Her ser vi at de fleste lærebøkene ikke har noen umarkerte bilder. Hadde bruk av umarkerte bilder gått på individuelle forfatteres smak, hadde vi kunnet forvente 
få som hadde bare 1 eller 2, og de resterende lærebøker med relativt mange. Men denne fordelingen viser at bare 4 av 52 lærebøker har flere enn 3 umarkerte bilder og en tredjedel av lærebøkene har 1-3, det vil si færre enn 1 per religion. Én lærebok pekte seg ut som uvanlig, den med 21: KRLE-Boka 5-7 brukte portrettbilder, 3 til hver religion, av elever som presenterte «tenkepauser». Bare én av disse var eksplisitt markert for religion: en jente med hijab. De andre fremstod som religiøst anonyme medelever. Ser man bort fra de elevene, var bare 7 umarkerte: 2 $\mathrm{i}$ kristendomskapitlet, og $5 \mathrm{i}$ buddhisme. Med andre ord, tendensene fremkommer på tvers av mange lærebøker og ser ikke ut til å skyldes individuelle forfatteres/ forlags smak.

\section{Del 2: Bildeanalyser}

Hvordan ser disse bildene ut? Med såpass få bilder å se på kan vi lett få oversikt. Spørsmålet nå er hvilke fagdidaktiske konsekvenser den avdekkede asymmetriske distribusjonen har - det at det finnes systematiske forskjeller mellom hvordan umarkerte bilder distribueres blant kapitler om navngitte religioner. Det virker usannsynlig at denne asymmetrien er tilsiktet. Vi har fortsatt ikke tilgang til klasseromsdata. I stedet skal jeg prøve å utarbeide bildenes didaktiske grammatikk. Hvordan lar de seg bruke? Gjennomgående vil jeg dra fram bare umarkerte bilder og spørre om deres pedagogiske funksjon ut fra deres egenart. Her er vi også interessert i bildenes kontekst som et spor på hvilken rolle de kan innta i en læringsprosess.

Når de 2050 sidene som vies hinduisme, islam og jødedom, bare gir oss 17 umarkerte bilder, kan vi begynne der. En underkategori med umarkerte bilder knyttet til disse religionene, er de som sikter mot kosmologi. Ett av de to bildene som tilhører hinduismen, viser et vakkert landskap uten mennesker (figur 3):

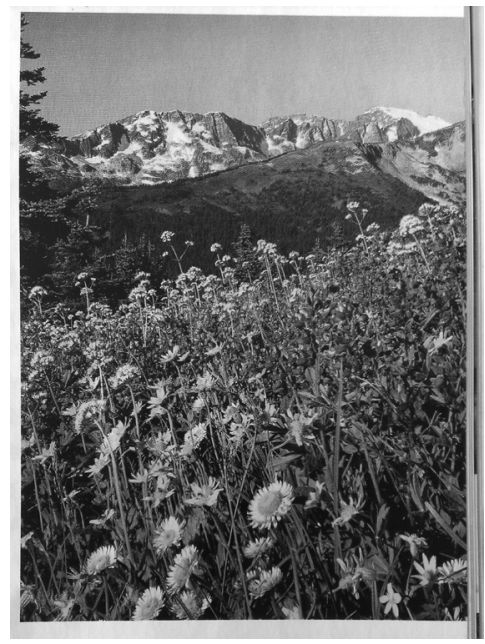

Figur 3 Hinduisme, Vivo 5-7: 237.

Bildet kunne godt ha blitt tatt i Norge: prestekrager og andre blomster, fjell og blå himmel. Dette kunne vært fra nærmiljøet til en norsk skole. Bildet viser oss ingenting religiøst, og fjellet har ingen religiøs betydning - så vidt jeg vet. Det eneste religiøse her er hvordan du selv oppfatter bildet. Under bildet står det «Hinduer tror 
at alt $\mathrm{i}$ hele universet henger sammen. Denne sammenhengen kalles dharma.» Teksten er distanserende: det er hinduer, ikke du og jeg, som tror dette, og innsikten uttrykkes ved et fremmedord. Ideen hører ikke hjemme i Norge. Allikevel inviteres elever til å dele innsikten ved å skue scenen fra et spesifikt ståsted. Bildet trekker leseren nærmere, teksten distanserer.

Alle jødedommens umarkerte bilder følger dette mønsteret eller viser portrettbilder (se over). Tidligere lærebokanalyser i religionsfagene har vist at behandlingen av jødedom har en sterk tendens til å legge vekt på elementer religionen deler med kristendom, og ikke rabbinske utviklinger som Talmud og middelaldersk filosofi. Dette er ikke uvanlig: i engelske læringsmaterialer var det også

a woeful lack of grip on the rabbinic tradition and a failure to quote from it, which is, after all, what most Jews deal with now. Today's Jews talk about Rashi and Rambam more than they do about Isaiah and the Psalms. The latter provide the backdrop for the grapplings of the former (Jackson et al., 2010, s. 110; se også s. 6).

I vårt utvalg illustrerer jødedommens umarkerte bilder skapelsestemaet, med ett bilde av skog og ett av havet. Dette er et tema som religionen deler med kristendom, og med utgangspunkt i Winjes funn om at allmenn religiøs læring kobles opp til kristendom i lærebøker, er ikke dette overraskende.

En annen underkategori er etiske bilder. Her gjelder det ikke mennesker fra en spesifikk religion som gjør etiske handlinger, for da ville de ikke blitt klassifisert som umarkerte bilder. De viser heller situasjoner der mennesker kan gripe inn for å gjøre en etisk handling. De som trenger hjelp, er heller ikke religiøst identifisert, så situasjonen er i utgangspunktet allmenn. For eksempel, i et kapittel om islam presenteres en mann med et protetisk bein, og noen har gitt ham penger (figur 4).

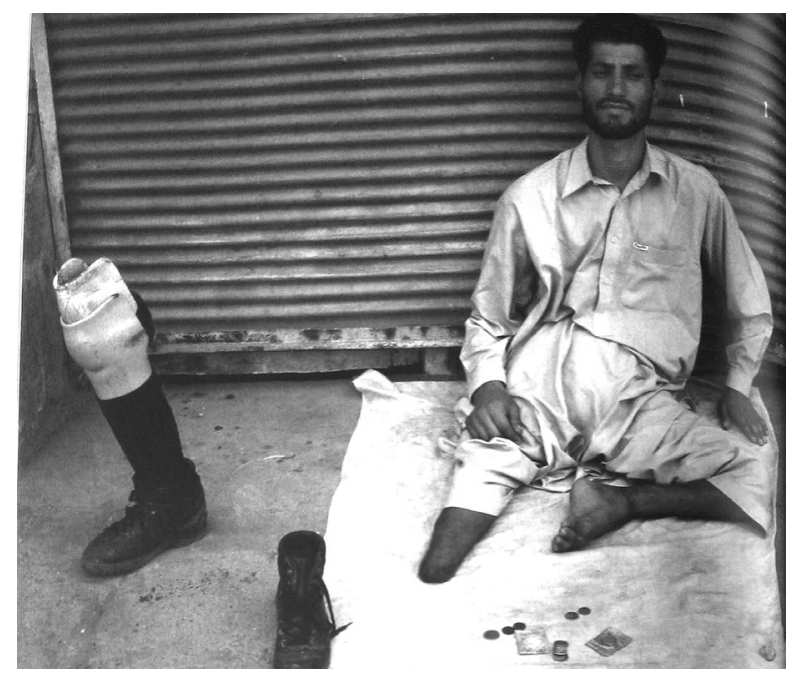

Figur 4 Islam, Under samme himmel 3: 170 
Pengene er nok ikke norske, og dette er ingen typisk scene fra et norsk tettsted. Men situasjonen er ikke ellers markert som fremmed. Teksten derimot plasserer etikken innen en religionsspesifikk sammenheng: den handler om velferdsbidraget som en av de fem søylene, og prinsippet er igjen gitt et navn fra et annet språk, zakah.

Hva lærer eleven om religion når de ser dette bildet? Selve bildet har ingen åpenbar religiøs relevans, og læreboka identifiserer ingen religiøse elementer $\mathrm{i}$ innholdet (man betaler ikke zakah med spesielt religiøse penger), så koblingen til religion må være i tolkningen. Jeg må se pengene som zakah. Religiøsiteten ligger i anskuelsen, ikke i selve bildet. Så snart jeg stiller spørsmål som «har de fattige krav på mine penger?» har jeg tenkt religiøst, og konteksten foreslår at jeg går i dialog med zhakat.

Alle umarkerte bilder innenfor kapitlene om hinduisme, islam og jødedom faller innenfor disse to kategoriene (unntatt portrettene): etikk og kosmologi. Kapitlene om buddhisme og kristendom dekker de samme områdene med sine umarkerte bilder, men de gir oss i tillegg nye temaer, for eksempel eskatologi som nirvana og oppstandelse.

Noen ganger kan det være vanskelig å forstå forbindelsen mellom tekst og bilde i vårt materiale. Både et stille hav og et geometrisk mønster brukes til å si noe om nirvana for eksempel. Eleven må selv tolke bildet på en religiøs måte for å lære om religion. Hverdagslige ting brukes til å tolke sammensatt lære med denne kategori bilder. Eleven oppfordres til å se religiøst på ting de møter i eget liv, som blomster eller en sommerfugl (Vivo 1-2: 141; Vivo 3-4: 183).

Kapitlene om kristendom inkluderer de overnevnte kategoriene, men i tillegg bruker de umarkerte bilder på særegne måter. Blant annet brukes umarkerte bilder til å forklare religiøse tekster. Historiske bøker i det gamle testamentet, for eksempel, illustreres i Store Spørsmål 8 med dette bildet (figur 5):

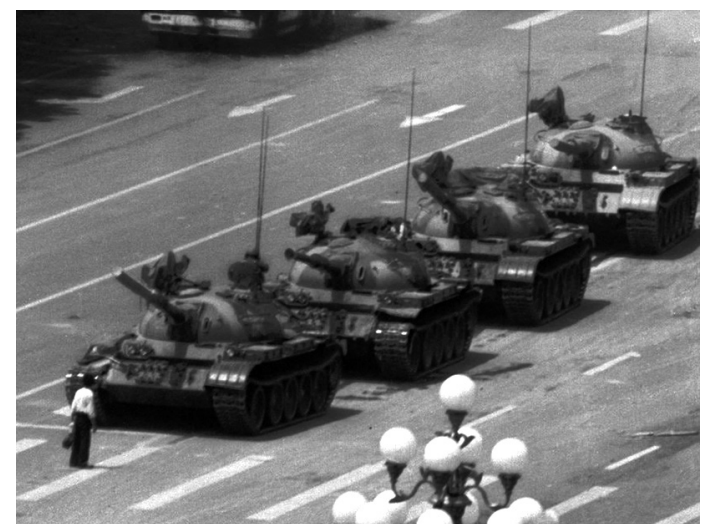

Figur 5 Kristendom, Store spørsmål 8: 99. Kilde: Jeff Widener fra Associated Press, av den berømte "Tank Man», 5. juni, 1989. 
Underteksten beskriver situasjonen som «En moderne David-og-Goliat-historie». Ingen religiøse markører ble oppdaget, nettopp fordi ingen av aktørene hørte til kapitlets religion (kristendom). Det religiøse handler om hvordan man tolker bildet. Akkurat som ved bildene om kosmologi og etikk over, gis tolkningsrammen en religionsspesifikk forankring («David og Goliat»), men bildet er religiøst umarkert.

Her oppfordres eleven til å tolke ikke bare hverdagen, men situasjoner som allerede kommer med en tydelig ideologisk ladning, med religiøse briller. «Tank Man» sier oss ganske mye, og innbyr til refleksjoner om menneskets kraft, om teknologi, mot og selvbestemmelse. Men her styrer den omkringliggende teksten i retning en kristen tolking av bildet; situasjonen koloniseres av en kristen tolkning.

Bildene av denne typen brukes gjerne for å lede leser fra en kjent situasjon til religionsspesifikk lære. Flere bilder av mennesker uten religiøs markering kobles opp til et åpent refleksjonsspørsmål: «hva forbinder du med ordet rettferdighet?» «hvorfor tror du noen [jobber frivillig]?» «Hvordan trøster vi hverandre?» «Hva mener du om oppfordringen: 'La alle mennesker få merke at dere er vennlige'?» (KRLE-boka 8-10: 149f, 152, 174) «Er [Al Gore] en moderne profet?» (Store spørsmål 8:105).

For å oppsummere, når vi ser på våre bilders kontekst i lærebøker, dras leseren i to retninger: på den ene siden kobler umarkerte bilder til elevens kjente livsverden (et fjell, et menneske, en form), og på den andre til religionsspesifikk lære (dharma, zakah, nirvana, profet). Bildets innhold giør den første jobben, få av de umarkerte bildene virker særlig ukjente. For å oppnå en kobling til religiøs lære derimot, må de tolkes i en spesifikk retning, og det krever en tekst som omtaler verden utenfor bildet (noe vi så bort fra for å kategorisere bildene i del 1).

\section{KonseKVEnSER}

Hvis du skulle forklare fenomenet YouTube for besteforeldre, barn eller romvesen har du to åpenbare strategier å velge mellom. Den første er å fortelle dem detaljer om tjenesten, for eksempel dens historie, nåværende eierskapsforhold, og gitt eksempler på berømte «YouTubere» som PewDiePie eller Justin Bieber. Men antakelig går du til strategi to og viser dem kattevideoer. Når du gjør det, har du også anledning til å bruke fullskjerm og fullstendig viske ut spor av selve YouTube, men samtidig får besteforeldrene en ide om tjenestens nytteverdi, og hvordan den åpner opp en hel verden av kattevideoer, film, videodagbøker og undervisning som har bare marginal tematisk tilknytning til videotjenester. Med mindre de også er opptatt av dataspill, er det ikke sikkert PewDiePies biografi kommer til å fenge.

Vi har en liknende mulighet når vi velger illustreringer i kapitler som rendyrker spesifikke religiøse tradisjoner. Vi kan velge mellom strategi 1 , å vise bilder av hellige hus, ritualer eller berømte religiøse mennesker, eller strategi 2 , å la religioner 
åpne opp et perspektiv på tilværelsen med fortellinger, verdensbilder eller etikk. Med mindre elever allerede er interessert i ritualer eller arkitektur, er det ikke sikkert strategi 1 fenger. Men strategi 2 overlapper med ideer elever allerede har en formening om. De har allerede hørt fortellinger når de leser om Ram og Sita; de har allerede grublet om sitt eget perspektiv når de hører om lidelsens opphav; de har allerede vurdert sine egne handlinger når de hører om religiøs etikk.

I vår pågående samtale om religion i skolen er disse strategiene allerede grundig diskutert som valget om «å lære om» religion overfor «å lære av» religion. I vårt datasett kan vi sortere umarkerte bilder som et eksempel på strategi 2. For å bruke dem innenfor strategi 1, måtte vi slå av fullscreen, vise til en innfløkt sammenheng, og forklare hvordan akkurat denne måten til å åpne opp verden på teller som religiøs.

Hva kjennetegner da strategi 2? Med vårt YouTube-eksempel så vi at den adresserte besteforeldrenes interesser, kunne fortelle om YouTube uten at selve tjenesten var synlig (fullskjerm). Den kunne også integreres inn i strategi 1 ved å gå ut av fullskjerm, og se hvordan videoene leveres i en YouTube-spesifikk kontekst, med muligheter til å like, abonnere på, og se på liknende kanaler og spillelister. Det samme gjelder umarkerte bilder: de viser gjerne ting som leseren har sett før, forteller om religion som ikke er synlig i selve bildet, men kan fortsatt integreres $i$ strategi 1 når man setter bildet $\mathrm{i}$ konteksten av en navngitt religiøs tradisjon.

Eksemplene vi analyserte ovenfor, var av kjente fenomener: et fjell, et fattig menneske, og et berømt bilde av en panservogn. Ingen av bildene inkluderte religiøs markering, men de åpnet opp for en verden av refleksjon (om henholdsvis kosmologi, etikk og politisk avmakt) som spesifikke tradisjoner bidrar til. Alle sammen ble integrert inn istrategi 1 ved sin sammenheng ilæreboka, med varierende grad av religionsspesifikke markører (fremmedord og fortelling). Akkurat slik som med YouTube, jo lenger en seer titter på bildet alene, uten sammenhengen, jo lenger benytter de seg av tjenesten eller religionen til å se på resten av verden. Jo snarere de slår av fullskjerm eller ser på bildet i sin sammenheng, jo snarere dras deres oppmerksomhet mot den spesifikke religionen. Når det skjer, har læringsobjektet skiftet fra en verden som religionen eller videotjenesten åpner for eleven, til den spesifikke religiøse tradisjonen eller leverandøren som åpnet den.

Strategi 2 er med andre ord bedre egnet til å lære elever å bruke tjenesten eller perspektivet, og strategi 1 holder den litt mer på avstand. Samtidig er det utenkelig at besteforeldre kommer til å forstå YouTube med mindre de ser en faktisk video. Det vil si at umarkerte bilder hjelper lesere til å innta et midlertidig religiøst perspektiv på verden, inntil konteksten tydeliggjøres. Det virker som et håpløst prosjekt å lære elever om et religiøst verdensbilde uten den opplevelsen.

Med disse to strategiene har jeg prøvd å utdype Winjes grunnleggende innsikt om koblingen mellom allmenne verdier og elevens opplevelse av distanse mellom 
seg selv og ulike typer bilder. Kort sagt: strategi 1 gir oss distanserte bilder; strategi 2 gir oss de nære.

Hvis umarkerte bilder er asymmetrisk distribuert blant navngitte religioner i lærebøkene våre, reiser det noen pedagogiske spørsmål om tilgang til de ulike strategiene. Utfordringene for lærere ligger i de fremstilte religionenes bidrag til refleksjon, sekularisme og nødvendige pedagogiske oppgaver.

\section{1: Religioner konstrueres som dannelse og eksotiske objekter}

Ujevn bruk av umarkerte bilder kan føre til ujevne bidrag til elevers menneskelige utvikling. I strategi 2 kan bilder gå i dialog med spørsmål elever allerede sitter med før religionsundervisningens intervensjon. Vi kan ta for oss et eksempel om meditasjon.

Mange religioner oppfordrer til meditasjon. Noen skoler håndterer meditasjon som en del av andre fag (Zetterqvist \& Skeie, 2014). Det er en aktuell aktivitet for elever. Et typisk umarkert bilde vil vise et meditasjonsobjekt som en blomst, solnedgang eller sommerfugl (Vivo1-2: 141), mens et bilde med religionsspesifikke markører gjerne viser et menneske som mediterer (I samme verden: 175). Umarkerte bilder retter læringen direkte til elevens evner til å meditere ved å foreslå at de ser på tilværelsen gjennom disse brillene, mens de religionsspesifikke retter læringen mot elevens kunnskap om religioner.

Det er ikke meningen å kritisere noen av bildene. Tvert imot: de har hver sin funksjon. Et umarkert bilde yter motstand mot eksotisering ved å presentere religiøs praksis og tankegods (strategi 2) som fornuftig og «aktuelle kilder til tro, moral og livstolkning» (Utdanningsdirektoratet, 2015, 2). Religionsspesifikke bilder, derimot, står imot en retusjert og teoretisk fremstilling av religion (strategi 1). Når vi ser bilder av religiøse mennesker, husker vi at disse ideene er koblet til religiøse grupper, og når vi kritiserer dem, omfavner dem eller transformerer dem, har vi med mennesker å gjøre i tillegg til ideer. Begge disse former for motstand er nødvendige religionsdidaktiske oppgaver.

Begge typer bilder har sin funksjon, men en ujevn distribusjon blant kapitler om navngitte religioner er uheldig, av to grunner. Den er usynlig, så lærere vet ikke hvordan de skal kompensere for at buddhister presenteres med den aktuelle lære, mens hinduer presenteres som eksotiske mennesker. I tillegg er den skjev i feil retning: tidligere forskning (Jackson et al., 2010; Thomas \& Rolin, 2018; Winje, 2003) har utpekt eksotisering som en fare for presentasjoner av islam, hinduisme og jødedom (som har få umarkerte bilder til å korrigere inntrykket). Samtidig er religiøse menneskers usynlighet (strategi 2) er et problem for presentasjoner av buddhisme og særlig global kristendom, som begge to lider av å bli presentert som idésystemer uavhengig av deres forankring i faktiske grupper mennesker i Norge 
og globalt. De mange umarkerte bildene viet disse to religionene i våre data gjør problemet verre.

\section{2: Religioner bidrar til sekulær samtale}

Det er en pågående samtale om hvorvidt religiøse innspill skal få adgang til det åpne samfunnets politiske debatt. En av de sterkeste stemmene i debatten i Norge stammer fra Habermas, som åpnet for religiøse bidrag uten å løsne på kravene om logikk og enighet (Habermas, 2005). Religiøs innsikt bør få adgang til åpne samtaler, bare det ikke forventes at alle deler ubegrunnede religiøse påstander. Betingelsen for inkludering i offentlig debatt er gode argumenter.

Umarkerte bilder gir adgang til en slik sekulær debatt, nettopp i kraft av at de fasiliterer overgang fra elevens sekulære livsverden til religionsspesifikk lære. Koblingen mellom en gjenkjennelig hverdag (i et umarkert bilde) og religiøs lære (sammenheng i læreboka) tilsvarer tolkningsarbeidet religiøse stemmer må gjøre når de bidrar til sekulær samtale: de må representere sine ideer uten religionsspesifikt innhold. Nettopp derfor utgjør de religiøs deltakelse i sekulær diskusjon.

I tillegg støtter umarkerte bilder religiøs tilgang til debatt ved at de begrunner innsikt. Når de går i dialog med elevens eget perspektiv, kommer de med gode argumenter for sin verdensanskuelse (strategi 2). De retter læringen mot allmenne problemstillinger.

Umarkerte bilder som distribueres ulikt i religionsundervisning, gir ulik tilgang til åpne sekulære debatter ved å presentere religiøs innsikt avskåret fra gruppetilhørighet, og med gode argumenter. Winje kaller dette for bildenes «eierskapsforhold». Ideer kan også ha sterke eller svake eierskapsforhold. Jo svakere de er, jo bedre tilgang til åpen dialog. Tilgang til åpen demokratisk samtale blir dermed urimelig skjev (Axner, 2015, s. 24).

\section{3: Klasseromsfelleskap}

Muligheten til å bidra til en felles og konstruktiv samtale har også konsekvenser for klasserommet. Hvis samtalen ikke gir lik tilgang for alle, blir den verken rettferdig eller forpliktende.

Betydningen av enighet for samhold har kommet under angrep i nyere tid spesielt fra Iversens bruk av begrepet «uenighetsfelleskap» (blant annet i Iversen, 2012). Ideen er at det slett ikke er avgjørende for en gruppes tilhørighetsfølelse at de er enige seg imellom om sentrale verdimessige spørsmål.

Slike formaninger om å ikke tillegge likhet og enighet for mye betydning er uten tvil på sin plass i dagens samfunn. Men to forbehold må noteres:

1 Noen saker krever fortsatt enighet. Sameksistens krever enighet om praktiske ordninger. Megling skjer. På lik linje takler klasserommet uenighet om mange spørsmål, for eksempel om etikk eller politikk, relevante saker som læreres 
myndighet og den moderne kunnskapens status. Men når det kommer til klasseregler, eksamensform, felles aktiviteter og elevens hverdag, krever læringsmiljøet og medvirkning at klassen kommer til enighet (som Iversen har selv påpekt i Aukland 2018). Enighet om noen spørsmål må prioriteres over enighet om andre. Avgjørelsen om hvilke spørsmål som har praktisk betydning og hvilke som er mindre vesentlige, vil også påvirke klassen på ulike måter. Føringer om klær hemmer noen mer enn andre og kan skape, heller enn løsne, religiøse forskjeller i et klasserom. Noen må svelge større kameler enn andre.

2 Bidragene til praktiske samtaler om felles anliggender har ulik status. Diskusjoner bør ta utgangspunkt i begrunnelser som fordrer allmenn enighet, der alle kjenner seg igjen og lar seg overtale. For religiøse elever vil religiøse grunner kanskje veie tyngst, men jo mer religionsspesifikke de er, jo mindre allmenn enighet vil de vinne. Religionene som fremmer religionsnøytrale poeng, vil dermed ha diskursmessig sterkere tilstedeværelse.

Enighet om religion er ikke et krav for samvær, men enighet om andre forhold er det. Religionene kan gi større eller mindre bidrag til de praktiske avgjørelsene. Umarkerte bilder er en av mange anledninger til å koble religiøse ideer til den typen allmenn samtale som styrer elevers hverdag. Refleksjonsspørsmålene koblet til umarkerte bilder som vi noterte ovenfor - «hva forbinder du med ordet rettferdighet?» «hvorfor tror du noen [jobber frivillig]?» «Hvordan trøster vi hverandre?» - brukes i lærebøker til å si noe om kristen lære. De kunne også vært et utgangspunkt for en dannelsessamtale om hva vi burde kunne forvente av hverandre, og hva vi ønsker skal prege vårt samvær. Slike spørsmål holder samtalen godt forankret i strategi 2 .

Læringsmiljøet er ett av forholdene som påvirker alle og som alle trenger å være enige om. Det ligger også til grunn for religionsdialog i klasserommet. Dersom læringsmiljø er et produkt av faktorer som hører mer hjemme i noen typer dogma enn andre (for eksempel, ulike varianter av «den gylne regelen»), vil også religionsdialogen og religionsundervisningen foregå på ujevne premisser.

\section{Motforestilling: ALLE Religioner ER IKKE LIKE}

Jeg åpnet med å si at ikke alle religioner er like. Er denne kritikken av den skjeve distribusjonen av umarkerte bilder et forsøk på å behandle dem som det? Vi kunne argumentere for at kapitler om religioner ikke skal ha samme type kunstverk eller tekster koblet til dem i læreverk. Kanoner utvikler seg på ulikt vis, og har ulik status innenfor forskjellige religiøse tradisjoner. De leses på forskjellig vis, siteres og behandles ulikt. Kunsttradisjoner varierer også fra sted til sted. Det er kanskje naturlig å ha forskjellige vektlegginger av arkitektur, skulptur, ornamenter og 
malerier hos ulike religioner. Religiøs kunst har også ulike forhold til ritualer og hellige rom, avhengig av hvilken tradisjon det er snakk om.

Disse er sterke motforestillinger, men illustrasjoner av kanoniske tekster og religionsspesifikke kunsttradisjoner utelukkes fra vår gruppe bilder. Det er ingen åpenbare skjevheter (utover demografisk tilhørighet) i feltet som bør kunne gjøre noen religioner til mer aktuelle inspirasjonskilder enn andre. I mellomtida sitter vi igjen med de tre overnevnte urettferdige klasseromskonsekvenser, enten de er begrunnet eller ei.

\section{KONKLUSJON}

Oppfatninger av religiøs innsikt som gyldige perspektiver på tilværelsen (strategi 2), og dermed som verdensbilder heller enn grupper mennesker, synes å være distribuert ulikt i lærebøkene. Umarkerte bilder inkluderer ingen synlig religiøse mennesker, men er anledninger for eleven til å gå i dialog med religionen.

Denne analysen kan anvendes i debatten om hvor involverende religionsfaget bør være. Det er lett å se for seg at noen kunne ønske bilder som bare synliggjør religiøs aktivitet, og andre kunne vektlegge umarkerte bilder som tilbyr ny innsikt i verden hos alle religionene. Umarkerte bilder kan sikkert bli kalt eksistensielle på den ene siden og empiriske på den andre. De første kan anklages for å være forkynnende, og de andre for å ha forlatt dannelsesoppdraget. Jeg har ikke lyst til å gå inn i den debatten, men klargjøre skillet. Uansett om vi ønsker mer av religionskunnskap eller religiøs kunnskap, må vi være opptatt av hvordan disse ulike typene kunnskap fordeles blant presentasjoner av religiøse tradisjoner og grupper. Hvis undervisning om visse religiøse tradisjoner og grupper handler bare om sosiologi, mens andre tradisjoner og grupper byr på allmenne perspektiver på verden, er det en kvalitetsforskjell.

Som vi har sett fra statistikken, har antall sider viet en religion noe å si for distribusjoner av umarkerte bilder, også når vi ser på frekvensdata. Noen typer bilder, for eksempel de umarkerte som brukes til å illustrere hellige tekster, finner vi bare i kapitler om kristendommen, som vies flere sider enn andre religioner. Kvantiteten kan sikkert forsvares og debatteres. Men når lærebokforfattere får mer plass til å behandle en spesifikk religion, skal det godt gjøres at de utvider stoffet med nøyaktig de samme tilnærmingene og metodene som de anvendte på de andre religionene. I praksis kan vi her sette et likhetstegn mellom kvantitetsmessig ulikhet og kvalitetsmessig ulikhet, selv om opplæringsloven gjør et tydelig skille (Sødal et al., 2009, ss. 97-100). Samtidig forklarer ikke kvantitet statistikken om buddhisme i det hele tatt.

Det er ikke åpenbart hvordan «Dei same pedagogiske prinsippa» skal se ut samtidig som en bevarer mangfold både i religioner og religionsdefinisjoner, men vi er ikke dermed fritatt fra å levere balansert undervisning. Mens debatten pågår 
om å lære av eller om religioner, distribueres undervisningsmetoder ulikt.

Det å få større innsikt i kvalitetsforskjeller i religionsundervisning, og arbeide med å sammenlikne hvordan religioner konstrueres i våre religionsklasser og læremidler, er viktig for det å ta religiøse forskjeller på alvor. Først da arbeider vi for en likestilt og rettferdig behandling av alle religiøse grupper i vår undervisning. ${ }^{4}$

\section{LitTERATUR}

Aukland, K. (2018). KRLEpodden. Oslo.

Axner, M. (2015). «Studying public religions. Visibility, authority and the public/ private distinction.» I T. Hjelm (Red.), Is God Back? Reconsidering the New Visibility of Religion (ss. 19-31). London: Bloomsbury.

Breidlid, H., \& Nicolaisen, T. (2011). I begynnelsen var fortellingen (2. utg. ed.). Oslo: Universitetsforlaget.

Cox, E. (1983). «Understanding Religion and Religious Understanding.» British Journal of Religious Education, 6(1), 3-13. doi:10.1080/0141620830060102

Habermas, J. (2005). «Religion in the Public Sphere.» Holberg lectures. Tilgjengelig på https://holbergprisen.no/sites/default/files/Habermas_religion_in_the_ public_sphere.pdf (nedlastet 1/2/19)

Hatlebrekke, K. (2018) «Pugge kritisk tenkning? Om religionskritikk i lærebøker for KRLE.» Prismet 69:2-3, 133-148.

Hickman, H., \& Porfilio, B. J. (Red.). (2012). The New Politics of the Textbook: Problematizing the Portrayal of Marginalized Groups in Textbooks (Vol. 1). Rotterdam: SensePublishers, Rotterdam.

Härenstam, K. (1993). Skolboks-islam Analys av bilden av islam i lärobøcker i religionskunskap. Acta Universitatis Gothoburgensis, Göteborg.

Iversen, L. L. (2012). Learning to Be Norwegian. A Case Study of Identity Management in Religious Education in Norway. Münster: Waxmann Verlag.

Jackson, R., Ipgrave, J., Hayward, M., Hopkins, P., Fancourt, N., Robbins, M., Francis, L., McKenna, U. (2010). Materials used to Teach about World Religions in Schools in England. Department for children, schools and families research report. Tilgjengelig på https://www2.warwick.ac.uk/fac/soc/ces/research/ wreru/research/completed/dcsf/reportdcsf-rr197.pdf (nedlastet 1/2/19)

Krippendorff, K. (2013). Content analysis. An introduction to its methodology. Thousand Oaks, California: Sage.

4 Takk til Geir Winje, Helene Selvik, Kari Ane Kvendseth, Harald Torgauten, Gunnfrid Øierud, deltakere på Norefo-konferansen 2018, og to anonyme fagfeller for at de drøftet og leste igjennom tidligere versjoner av denne artikkelen. Alle resterende feil og manglende innsikt er naturligvis mine egne. Takk også til vennlige ansatte på Gyldendal, Aschehoug og Cappelen Damm som ga meg tilgang til elektroniske versjoner av de lærebøkene jeg ba om. 
Kunnskapsdepartementet. (2016) Lov om grunnskolen og den vidaregåande opplæringa (opplæringslova). Tilgjengelig på: https://lovdata.no/lov/1998-07-17-61 (nedlastet 15/2/20)

Midtbøen, A. H., Orupabo, J., \& Røthing, Å. (2014). Beskrivelser av etniske og religiøse minoriteter $i$ læremidler. Tilgjengelig på: https://www.udir.no/globalassets/upload/forskning/2014/isf-rapport-2014-10_trykklar.pdf (nedlastet $1 / 2 / 19)$

Neuendorf, K. A. (2002). The content analysis guidebook. Thousand Oaks, California: Sage.

Sødal, H. K., Danielsen, R., Eidhamar, L. G., Hodne, H., Skeie, G., \& Winje, G. (2009). Religions- og livssynsdidaktikk. En innføring (4. utg.). Kristiansand: Høyskoleforlaget.

Thobro, S. A. (2008). Representasjoner av buddhisme og hinduisme. En diskursanalyse i postkolonialt perspektiv av lærebøker i religionsfaget for gymnas/videregående skole. Universitetet i Bergen, Bergen.

Thobro, S. A. (2014). «Cartographic Representations of Religion(s) in Norwegian Textbooks.» I B.-O. Andreassen \& J. R. Lewis (Red.), Textbook Gods. Genre, Text and Teaching Religious Studies (ss. 157-171). United Kingdom: Equinox eBooks Publishing.

Thobro, S. A. (2017). «Representations of Anti-Semitism and the Holocaust in RE Textbooks for Norwegian Upper Secondary School.» I B. O. Andreassen, J. R. Lewis, \& S. A. Thobro (Red.), Textbook Violence (ss. 98-125). Sheffield: Equinox.

Thomas, A., \& Rolin, A. (2018). «Reading religion in Norwegian textbooks. Are individual religions ideas or people?» British Journal of Religious Education, 1-13. doi:10.1080/01416200.2018.1484691

Undheim, S. (2017). "Aniconism and Images in Norwegian RE-textbooks. Representations and Historical Change.» I B. O. Andreassen, J. R. Lewis, \& S. A. Thobro (Red.), Textbook Violence (ss. 126-150). Sheffield: Equinox.

Utdanningsdirektoratet. (2006). Læreplan i religion og etikk. Fellesfag i studieforberedende utdanningsprogram. Tilgjengelig på: https://www.udir.no/k106/REL1-01 (nedlastet 1/2/19)

Utdanningsdirektoratet. (2015). Læreplan $i$ kristendom, religion, livssyn og etikk (KRLE). Tilgjengelig på https://www.udir.no/k106/RLE1-02 (nedlastet $1 / 2 / 19)$

Vestøl, J. M. (2016). «Textbook Religion and Lived Religion. A Comparison of the Christian Faith as Expressed in Textbooks and by Young Church Members.» Religious Education 111 (1):95-110. doi: 10.1080/00344087.2016.1124015.

Vestøl, J. M., Gundersen, K., Kristiansen, H. H., og Samdal, A. G. (2016). «Religion in Textbooks and among Young Buddhists, Hindus and Muslims. A Comparative Study.» Acta Didactica Norge 8 (1). 
Winje, G. (2003). Valg og vurdering av kunstbilder i KRL. Tønsberg, Høgskolen i Vestfold Rapport 2/2003. Tilgjengelig på http://www-bib.hive.no/tekster/ hveskrift/rapport/2003-02/rapport2-2003.pdf (nedlastet 1/2/19)

Winje, G. (2012). Guddommelig Skjønnhet. Kunst i religionene. 2. utgave. Oslo: Universitetsforlaget.

Winje, G. (2014). «Elevers lesing av bilder i RLE.» Norsk Pedagogisk Tidsskrift, 98(5), 341-351.

Winje, G. (2018). «Kritisk og upartisk? Utilsiktet religionskritikk i lærebøker for KRLE.» Prismet 69:2-3, 149-164.

Zetterqvist, K. G., \& Skeie, G. (2014). «Religion i skolen. Her, der og hvor-somhelst?» Norsk pedagogisk tidsskrift, 98(5), 304-315.

\section{LÆREBØKENE \\ Videregående:}

Aronsen, C. F., Bomann-Larsen, L., \& Notaker, H. (2008). Eksistens. Religion, etikk, livssyn, filosofi (Bokmål ed.). Oslo: Gyldendal undervisning.

Heiene, G., Myhre, B., Opsal, J., Skottene, H., \& Østnor, A. (2014). Tro og tanke. Religion og etikk for den videregående skolen (Bokmål ed.). Oslo: Aschehoug.

Kvamme, O. A., Steineger, A., \& Lindhardt, E. M. (2013). I samme verden. Religion og etikk (Bokmål ed.). Oslo: Cappelen Damm.

\section{Grunnskolen:}

Børresen, B., Larsen, T., Nustad, P., \& Berg, M. A. (2006-8). Vi i verden 1-7. Oslo: Cappelen Damm.

Hodne, H., Sødal, H. K., Syse, H. (2009-11). Du og jeg 1-7. Oslo: Cappelen Damm.

Engen, D. A. A., Eriksen, E-A. V., Iversen, R., Næss, E., Skarpeid, J., Sværen, J. H., Jangaard, A-R., Therkelsen, M., Øierud, G. L., \& Thomassen, M. (2009-11). Inn i livet 1-7. Oslo: Det Norske Samlaget.

Egeland, E., Husan, A. G. I., Jacobsen, K. C. D., Schjelderup, A. B., Bondevik, J. H., \& Borgersen, A. (2009-10). Vivo 1-7. Oslo: Gyldendal.

Winje, G. (2002-3). Hellige rom. Oslo: Aschehoug.

Waale, R. B., Wiik, P., \& Berge, E. (2000-1). Høytidene. Oslo: Cappelen.

Bondevik, J. H., \& Egeland, E. (2010). Vivo fortellingsbok. Oslo: Gyldendal.

Heien, F., Moseng, E., Møkleby, P. R., Haanes, E., \& Vigestad, K. (2011). Cogito 5-7. Oslo: Det Norske Samlaget.

Hove, O., Jørgensen, J. A., Rasmussen, J., \& Sandboe, M. (2015-17). Store Spørsmål 8-10. Oslo: Aschehoug. 
Børresen, B., Skrefsrud, T.-A., \& Hammer, A. B. (2017). KRLE-boka 5-7. Oslo: Cappelen Damm.

Waale, R. B., \& Wiik, P. (2016). KRLE-boka 8-10. Oslo: Cappelen Damm.

Waale, R. B., \& Wiik, P. (2002-3). Under samme himmel 8-10. Oslo: Cappelen Damm.

Holth, G., Deschington, H., von der Lippe, M., \& Kallevik, K. A. (2006-8). Horisonter 8-10. Oslo: Gyldendal.

Helskog, G. H., \& Ribe, A. (2006-7). Dialogos 8-9. Bergen: Fagbokforlaget. 


\section{VEDLEGG}

Umarkerte bilder sortert etter læreverk og kapittel

\begin{tabular}{|l|l|l|l|l|l|}
\hline & Kristendom & Buddhisme & Hinduisme & Islam & Jødedom \\
\hline Tro og Tanke & 4 & 1 & 0 & 0 & - \\
\hline Eksistens & 1 & 0 & - & 0 & - \\
\hline I samme verden & 1 & 0 & 0 & 0 & 0 \\
\hline Vi i verden 4 & 1 & 0 & 0 & 0 & 0 \\
\hline Vi i verden 7 & 3 & 0 & 0 & 0 & 0 \\
\hline Du og jeg 6 & 2 & 1 & 0 & 0 & 0 \\
\hline Du og jeg 7 & 2 & 0 & 0 & 1 & 0 \\
\hline Inn i livet 3 & 0 & 0 & 1 & 0 & 0 \\
\hline Inn i livet 5 & 1 & 0 & 0 & 2 & 0 \\
\hline Inn i livet 7 & 1 & 1 & 0 & 0 & 0 \\
\hline Vivo 1-2 & 3 & 4 & 0 & 0 & 1 \\
\hline Vivo 3-4 & 1 & 2 & 0 & 0 & 0 \\
\hline Vivo 5-7 & 1 & 0 & 1 & 0 & 0 \\
\hline Store spørsmål 8 & 2 & 0 & 0 & 0 & 1 \\
\hline Store spørsmål 9 & 1 & 1 & 0 & 0 & 0 \\
\hline Store spørsmål 10 & 1 & 1 & 0 & 0 & 0 \\
\hline KRLE 5-7 & 5 & 8 & 3 & 2 & 3 \\
\hline KRLE 8-10 & 10 & 3 & 0 & 1 & 0 \\
\hline Under samme himmel 8 & 3 & 0 & 0 & 0 & 0 \\
\hline Under samme himmel 9 & 2 & 0 & 0 & 0 & 0 \\
\hline Under samme himmel 10 & 0 & 0 & 0 & 1 & 0 \\
\hline Horisonter9 & 1 & 0 & 0 & 0 & 0 \\
\hline Horisonter 10 & 1 & 0 & 0 & 0 \\
\hline & 1 & 0 & 0 & 0 & 0 \\
\hline
\end{tabular}


De følgende lærebøker inneholdt ingen umarkerte bilder:

Hellige rom Buddhisttempel

Hellige rom Kirken

Hellige rom Hindutempel

Hellige rom Synagogen

Hellige rom Moskeen

Vi i verden 1

Vi i verden 2

Vi i verden 3

Vi i verden 5

Vi i verden 6

Du og jeg 1

Du og jeg 2

Du og jeg 3

Du og jeg 4

Du og jeg 5

Inn $i$ livet 1

Inn $i$ livet 2

Inn $i$ livet 4

Inn $i$ livet 6

Cogito 5

Cogito 6

Cogito 7

Horisonter 8 